\title{
The Gastrodia Antifungal Protein (GAFP-1) and Its Transcript Are Absent from Scions of Chimeric-grafted Plum
}

\author{
Alexis K. Nagel \\ Department of Genetics and Biochemistry, Clemson University, Clemson, SC \\ 29634

\section{Hetal Kalariya and Guido Schnabel ${ }^{\mathbf{1}}$ \\ Department of Entomology, Soils, and Plant Sciences, Clemson University, 114 Long Hall, Clemson, SC 29634}

Additional index words. GMO, phloem, translocation, disease tolerance, stone fruit, woody, rootstock, monocot-mannose binding lectin, transgenic, genetically modified

\begin{abstract}
The Gastrodia antifungal protein (GAFP-1) is a monocot mannose-binding lectin found in the Asiatic orchid Gastrodia elata. Transgenic plum (Prunus domestica var. 'Stanley') lines (4J and 4I) expressing GAFP-1 exhibit enhanced disease resistance to the stramenopile pathogen Phytophthora cinnamomi and the root-knot nematode Meloidogyne incognita. Rootstocks created from such transgenic lines might be more readily accepted by consumers if it can be shown that foreign gene products are not migrating into a grafted, nontransgenic scion on which fruit is produced. In this study, wild-type (WT) plum tissue was budded onto transgenic plum lines $4 \mathrm{~J}$ and $4 \mathrm{I}$ to create chimeric-grafted trees. Tissues from chimeric-grafted trees were analyzed for gafp-1 transcripts (leaf and root) and protein (leaf, soft shoot, and root) by reverse transcription-polymerase chain reaction and immunodetection, respectively. Transcripts of gafp-1 were detected consistently in the root tissues but not within the leaves of the grafted, WT scions. Similarly, the GAFP-1 lectin was identified within the roots, but not in the soft shoot or leaf tissues of the grafted, WT scions. These results suggest that gafp-1 mRNA and protein are not moving into the WT scion tissues of chimeric-grafted plum trees.
\end{abstract}

Development of genetically modified (GM) agricultural crops has given producers new options to combat pests and diseases. These transgenic options can be limited, however, depending on the type of crop and the nature of the affliction. For instance, despite the important economic impacts that root diseases can have on fruit production, only a few GM fruit tree species have been engineered for resistance to root-associated pathogens (Petri and Burgos, 2005). Transgenic plum (Prunus domestica var. 'Stanley') lines (designated 4J and 4I) expressing an isoform of the Gastrodia antifungal protein, GAFP-1-VNF (hereafter referred to as GAFP-1), are one example of such an engineered fruit tree system. These

Received for publication 27 Aug. 2009. Accepted for publication 16 Nov. 2009.

This study was funded in part by USDA-CSREES S-RIPM grant no. 2005-34103-15588 and USDACSREES special grant no. 2004-34126-14388 under project number SC-1000642 as well as USDA NRI grant no. 2002-35319-12527 and the South Carolina Peach Council.

Technical Contribution No. 5683 of the Clemson University Experiment Station.

We thank Dr. Desmond Layne of Clemson University for technical advice.

${ }^{1}$ To whom reprint requests should be addressed; e-mailschnabe@clemson.edu. tissues were analyzed for the presence or absence of gafp-1 mRNA and protein.

\section{Materials and Methods}

Generation of chimeric-grafted and autografted trees. Transgenic plum (Prunus domestica var. 'Stanley') lines 4J and 4I (Nagel et al., 2008) and nontransformed WT plum lines were used in this study. Both transgenic 4J and 4I lines express the gafp-1 gene under the control of the CaMV-35S promoter sequence (Plant Genetic Systems N.V., Gent, Belgium). Trees from 4J and 4I lines were clonally propagated from their respective mother $\left(\mathrm{T}_{0}\right)$ lines. WT trees, however, originated from different 'Stanley' seeds and thus represented some, albeit limited, inherent genetic variation within the WT population.

WT scion tissue was chip-budded (hereafter referred to as "budded") onto three transgenic 4J and 4I trees and three nontransformed WT trees (Fig. 1). Briefly, dormant bud tissue was excised from the scions of donor (WT) and recipient (4J, 4I, or WT) rootstocks. The donor bud was then placed onto the chipped area of the recipient rootstock stem. Buds from 1-year-old WT scions were budded onto the stems of 1-year-old 4J and $4 \mathrm{I}$ lines to create chimeric-grafted (CG) trees. Buds from 1-year-old WT plum were budded onto stems of 1-year-old WT plum (originating from different seeds) to create autografted (AG) trees. AG trees served as negative controls for the detection of gafp-1 mRNA and protein. Three tree replicates received two buds each for a total of six budding attempts per line. Buds were wrapped in Parafilm ${ }^{\circledR}$ (Pechiney Plastic Packaging Company, Chicago, IL) for 2 weeks. After this time, the Parafilm ${ }^{\circledR}$ was removed. Four weeks after the budding event, the WT scion was truncated just above the uppermost bud graft. If two buds flushed on the same tree, they were both allowed to develop on the stem. Ungrafted (UG) trees were kept as additional controls for the detection of gafp-1 molecular products in tissues. Trees were maintained in a biosafety Level 2 greenhouse under constant temperature $\left(27 \pm 5^{\circ} \mathrm{C}\right)$ and light conditions (16/8 h day/night).

Tissue sampling. Leaf, shoot, and root tissues were sampled from CG, AG, and UG trees for molecular analysis. Sampling of both grafted and ungrafted tissues continued over a 24 -month period. During this time, trees were pruned every 6 months. The grafted scions were truncated $\approx 3$ to 5 inches above the graft union.

Newly emerged leaves were sampled from just below the apical meristem beginning 2 weeks after maintenance pruning, and partially lignified root tissue was sampled from the tips of the plum tree roots. Unlignified, soft shoots were sampled from trees between 2 and 6 weeks after maintenance pruning. Two weeks was the minimum amount of time it took for axillary buds to flush new, expanded leaves exhibiting noncurled edges. For each line, leaf tissues were taken from a total of three grafted scions on at least two different 
$\mathbf{A}$

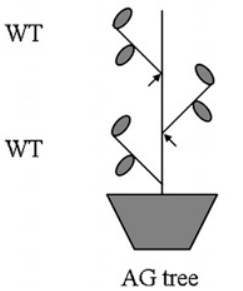

B

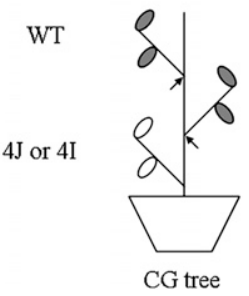

Fig. 1. A schematic diagram of the trees used in grafting experiments. (A) Wild-type (WT) plum tissue was budded onto WT rootstocks to create autografted (AG) trees. AG trees served as negative controls. (B) WT plum tissue was budded onto rootstocks from transgenic plum lines $4 \mathrm{~J}$ and $4 \mathrm{I}$ to create chimericgrafted (CG) trees. WT rootstock and scion tissues are indicated in gray; transgenic tissues are indicated in white. Two buds were budded per rootstock. Black arrows indicate the graft junction occurring on the rootstock stem.

CG and AG trees. Root tissues were sampled from corresponding trees. When possible, leaf tissue was sampled from grafted scions on separate trees. Leaf and root tissues were also sampled from three UG 4J, three UG 4I, and three UG WT trees. Soft shoots were sampled from two grafted scions on separate $\mathrm{CG}, \mathrm{AG}$, and UG trees from each line.

Detection of gafp-1 transcripts. Reverse transcriptase-polymerase chain reaction (RTPCR) was used to determine if gafp-1 transcripts were present in leaf and root tissues of $\mathrm{CG}, \mathrm{AG}$, and UG trees. Plant tissue $(100 \mathrm{mg})$ was ground in liquid nitrogen and total RNA was extracted using the RNeasy® Plant Mini Kit (Qiagen, Valencia, CA) according to the manufacturer's instructions. Total RNA (1 $\mu \mathrm{g})$ was reverse-transcribed to cDNA using the SuperScript ${ }^{\mathrm{TM}}$ First-Strand Synthesis System (Invitrogen Corporation, Carlsbad, CA) according to the manufacturer's instructions. Control reactions were performed for all samples in which $\mathrm{dIH}_{2} \mathrm{O}$ (deionized water) was substituted for the RT enzyme. These were included to verify that genomic DNA contamination was not present. Otherwise, parameters for cDNA synthesis remained the same. RNA concentration was determined using a GeneQuant pro spectrophotometer (Biochrom Ltd., Cambridge, UK) at $260 \mathrm{~nm}$. The RT procedure is documented to produce cDNA from as little as $1 \mathrm{ng}$ of total RNA (Invitrogen Corporation).

Root and leaf tissue-derived cDNAs were selectively amplified using gene-specific primers (Table 1). Tissues were analyzed for gafp- 1 transcripts by amplifying cDNA (5 $\mu \mathrm{L}$ first-strand synthesis) with primers 1 and 2, which are specific to the gafp-1 transcript sequence (NCBI accession number AJ277786). Because gafp-1 transcripts were expected to be absent in WT tissues, additional reactions had to be conducted to verify proper cDNA amplification. Leaf tissue cDNA synthesis was confirmed by PCR amplification with primers 3 and 4, which are specific to the catalase 2 (cat2) transcript sequence from peach (Prunus persica) (accession number AJ496419). Root tissue cDNA was PCRamplified with primers 5 and 6 specific to the $\alpha$-tubulin $(\alpha-t u b)$ transcript sequence from almond (Prunus dulcis) (NCBI accession number X67162). PCR amplification of all samples was performed with a Bio-Rad iCycler Version 4.006 (Bio-Rad Laboratories, Hercules, CA). Cycling parameters were as follows: initial denaturation at $95{ }^{\circ} \mathrm{C}$ for 2 min, 35 cycles of $94{ }^{\circ} \mathrm{C}$ for $30 \mathrm{~s}, 65^{\circ} \mathrm{C}$ for $30 \mathrm{~s}$, and $72^{\circ} \mathrm{C}$ for $40 \mathrm{~s}$; final elongation was at $72{ }^{\circ} \mathrm{C}$ for $10 \mathrm{~min}$. The entire procedure (mRNA isolation and RT-PCR analysis) was repeated for all tissues.

Detection of GAFP-1. Immunoblot analysis was used to determine if the GAFP-1 lectin (expected size $12 \mathrm{kDa}$ ) was present in leaf and root tissues of $\mathrm{CG}, \mathrm{AG}$, and $\mathrm{UG}$ trees. Total protein was extracted from leaf, shoot, and root tissues. Plant tissues $(300 \mathrm{mg})$ were homogenized in liquid nitrogen and total cellular protein was extracted with TRIzol Reagent $($ ) (Invitrogen Corporation) according to standard methods (Chomczynski, 1993). Soluble protein was dissolved in $1 \%$ sodium dodecyl sulfate (SDS). The total protein concentration for each sample was determined with the DC (detergent-compatible) Protein Assay (Bio-Rad Laboratories) according to the manufacturer's instructions. Bovine serum albumin was used as a standard. Sample absorbance was quantified at $650 \mathrm{~nm}$ using an Emax ${ }^{\circledR}$ precision microplate reader (MDS Analytical technologies, Sunnyvale, CA).

Total protein $(20 \mu \mathrm{g})$ was loaded onto a $15 \%$ Tris-HCl gel and separated by SDSPAGE. Protein molecular weight markers were included in all analyses (Precision Plus Protein $^{\text {TM }}$ dual color standard; Bio-Rad Laboratories). Proteins were tank-transferred to a PVDF membrane for $18 \mathrm{~h}$ at $30 \mathrm{~V}$. Membranes were blocked with $5 \%$ dry nonfat milk in TBST [ $(20 \mathrm{~mm}$ Tris- $\mathrm{HCl}, 140 \mathrm{~mm} \mathrm{NaCl}$, $\mathrm{pH} 7.5)+0.1 \%$ Tween 20], rinsed twice, and then incubated with purified, polyclonal GAFP-1 antibodies (1:1000 dilution) in 1\% dry nonfat milk + TBST. Membranes were rinsed three times and then incubated with goat, antirabbit alkaline-phosphatase (AP)conjugated secondary antibodies (1:2500 dilution) (Promega Corp., Madison, WI) in 1\%

Table 1. Primers used for amplification of cDNAs from leaf and root tissues.

\begin{tabular}{lllll}
\hline Primer & Target gene & Size & Orientation & Sequence \\
\hline 1 & gafp- 1 & $367-\mathrm{bp}$ & forward & $5^{\prime}$-CCTGTTCTTTCGCGTGACAACAGT-3' \\
2 & gafp-1 & & reverse & $5^{\prime}$-GTGTGGGTTGCCCAAATCGCATT-3' \\
3 & catalase 2 & $572-\mathrm{bp}$ & forward & $5^{\prime}$-AGGCACATGGAAGGCTCTAGTGTT-3' \\
4 & catalase 2 & & reverse & $5^{\prime}$-ACCTCCTCATCCCTGTGCATGAAA-3' \\
5 & $\alpha$-tubulin & $498-\mathrm{bp}$ & forward & $5^{\prime}$-TTGACATTGAGCGACCCACCTACA-3' \\
6 & $\alpha$-tubulin & & reverse & $5^{\prime}$-TGGTCGAGTTGGAGATCATGCACA-3' \\
\hline
\end{tabular}

dry nonfat milk + TBST. Membranes were developed with BCIP/NBT solution (Sigmafast $^{\mathrm{TM}}$; Sigma Aldrich, St. Louis, MO). The entire procedure (protein isolation and immunoblot analysis) was repeated for all tissues. The AP-conjugated secondary antibody is documented to detect as little as $10 \mathrm{pg}$ of protein (Bio-Rad Laboratories).

\section{Results}

With one exception, at least one of the two budding attempts became successfully established on each replicate tree. One tree from line $4 \mathrm{~J}$ failed to yield successful bud grafts. Successfully grafted buds began to flush $\approx 3$ to 4 weeks after budding.

The expected 367-bp gafp-1 and 498-bp $\alpha$-tub fragments were successfully amplified from root tissue cDNAs of CG $4 \mathrm{~J}$ and $\mathrm{CG} 4 \mathrm{I}$ trees (Fig. 2A). However, even after 35 cycles of amplification, we were not able to detect gafp-1 transcripts by RT-PCR in leaf tissues taken from WT scions of CG $4 \mathrm{~J}$ or $\mathrm{CG}$ 4I trees (Fig. 2B). Successful amplification of the expected 572-bp cat 2 fragment confirmed the quality of the mRNA extracted from these leaf tissues (Fig. 2B). Transcripts of gafp- 1 were not detected in the leaf or root tissues of UG WT or AG trees, but gafp-1 fragments were consistently amplified from leaf and root tissue cDNAs of transgenic UG 4J and UG 4I trees (Table 2). Cat2 and $\alpha-t u b$ transcripts were detected in leaf and root tissues, respectively, from all $\mathrm{CG}, \mathrm{AG}$, and UG trees. Duplicates of every sample were created at the RNA extraction stage and subjected to the entire procedure without the inclusion of the RT enzyme. This confirmed that cDNA-derived amplicons were not a result of genomic DNA contamination (Fig. 2A-B).

GAFP-1 (expected size $12 \mathrm{kDa}$ ) was detected in roots of $\mathrm{CG} 4 \mathrm{~J}$ and $\mathrm{CG} 4 \mathrm{I}$ trees but not in the leaf or soft shoot tissues of grafted, WT scions (Fig. 3A-B). In contrast, the lectin was detected consistently in the leaf and root tissues of UG 4J and UG 4I trees (Fig. 3C). A GAFP-1 signal was not detected in leaf, soft shoot, or root tissues from UG WT or AG trees (Table 2; Fig. 3A-C). Lignified tissues from grafted, WT scions of CG trees were not analyzed for gafp-1 products in this study.

GAFP-1 antibodies showed crossreactivity with other proteins on the immunoblots; however, crossreaction was not observed at the $12-\mathrm{kDa}$ position. Antibody crossreaction occurred with an unknown $14 \mathrm{kDa}$ protein in protein extracts taken from leaf, shoot, and root tissues and with a $15 \mathrm{kDa}$ protein in protein extracts from shoot and root tissues. Although the binding specificity of the GAFP-1 polyclonal antibody may have been optimized by loading a smaller amount of protein on the gels, we chose to load higher amounts of total protein $(20 \mu \mathrm{g})$ in an effort to resolve small amounts of GAFP-1 that may have been moving from the rootstock into the leaf tissues of the grafted, WT scion. On the immunoblots, the intensity of GAFP-1 bands 
(3)

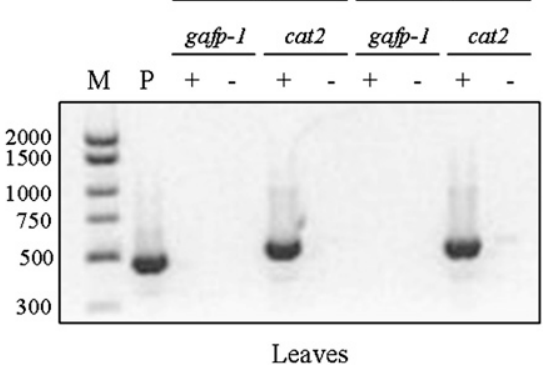

Fig. 2. Reverse transcriptase-polymerase chain reaction (RT-PCR) analysis of (A) root and (B) leaf tissues from rootstocks and grafted, wild-type scions of chimeric-grafted trees, respectively. Gafp-1 (expected size $367 \mathrm{bp}$ ) and $\alpha$-tubulin ( $\alpha$-tub; expected size $498 \mathrm{bp}$ ) or catalase (cat2; expected size $572 \mathrm{bp}$ ) transcripts were RT and PCR-amplified with sequence-specific primers. A plus $(+)$ or minus $(-)$ sign indicates the inclusion or exclusion, respectively, of the RT enzyme during cDNA synthesis. Chloramphenicol acetyltransferase (P; expected size $500 \mathrm{bp}$ ) RNA was RT and amplified with gene-specific primers (provided by SuperScript ${ }^{\mathrm{TM}}$ First-Strand Synthesis System; Invitrogen Corporation) as a positive control for cDNA synthesis and amplification. The numbers to the left of the figures indicate the size of the DNA markers $(\mathrm{M})$ in base pairs (exACTGene ${ }^{\circledR}$ Low Range DNA Ladder; Fisher Scientific, Pittsburgh, PA).

Table 2. Detection of gafp-1 mRNA and protein in tissues of autografted (AG), ungrafted (UG), and chimeric-grafted $(\mathrm{CG})$ trees.

\begin{tabular}{|c|c|c|c|c|c|c|c|c|}
\hline \multirow{2}{*}{\multicolumn{2}{|c|}{ Tree }} & \multirow[b]{3}{*}{ Observations $^{y}$} & \multicolumn{6}{|c|}{ Plant tissue ${ }^{z}$} \\
\hline & & & \multicolumn{2}{|c|}{ Leaf } & \multicolumn{2}{|c|}{ Root } & \multicolumn{2}{|c|}{ Shoot } \\
\hline Rootstock & $\overline{\text { Graft type }}$ & & $\overline{\mathrm{mRNA}}$ & Protein & $\overline{\mathrm{mRNA}}$ & Protein & Observations $^{\mathrm{x}}$ & Protein \\
\hline Wildtype & UG & $\mathrm{n}=3$ & - & - & - & - & $\mathrm{n}=2$ & - \\
\hline Wildtype & AG & $\mathrm{n}=2$ & - & - & - & - & $\mathrm{n}=2$ & - \\
\hline $4 \mathrm{~J}$ & UG & $\mathrm{n}=3$ & + & + & + & + & $\mathrm{n}=2$ & + \\
\hline $4 \mathrm{~J}$ & CG & $\mathrm{n}=2$ & - & - & + & + & $\mathrm{n}=2$ & - \\
\hline 4I & UG & $\mathrm{n}=3$ & + & + & + & + & $\mathrm{n}=2$ & + \\
\hline 4I & $\mathrm{CG}$ & $\mathrm{n}=3$ & - & - & + & + & $\mathrm{n}=2$ & - \\
\hline
\end{tabular}

${ }^{\mathrm{z}}$ Leaf, shoot, and root tissues were analyzed twice for the presence $(+)$ or absence (-) of gafp- 1 transcripts or protein.

${ }^{y}$ Number of trees from which leaf and root tissues were sampled.

${ }^{x}$ Number of trees from which soft shoots were sampled.

varied among protein samples taken from different tissues. This occurred although the amount of total protein loaded on the gel remained constant. This variation in band density was likely the result of some inconsistencies in the homogenization of the fibrous plant tissues.

\section{Discussion}

Many phloem-mobile macromolecules have been shown to traverse a graft union formed between compatible plant tissues. In situ RT-PCR studies demonstrated that pumpkin-derived $C m N A C P$ mRNA was present within the functional sieve elements (SEs) of grafted cucumber scions (Ruiz-Medrano et al., 1999). Gomez et al. (2005) showed that an RNA-binding phloem lectin from melon, CmmLec17, could be detected within the phloem exudate of heterografted pumpkin tissues. Grafting experiments between transgenic and WT tissues have demonstrated that transcripts may move through graft junctions and elicit responses in plant cells that do not contain the causal gene. Transcripts of the tomato PFP-LeT6 gene, a sequence fusion found exclusively in the dominant mutant Mouse ears, were able to move across a graft union and induce changes in leaf pinnation in
WT tissues (Kim et al., 2001). St BEL5 transcripts were translocated across grafts made between potato overexpression lines and WT rootstocks, and localization of St BEL5 in stolon tips resulted in a twofold increase in tuber yields (Banerjee et al., 2006). Macromolecules have even been observed to move across graft unions established in host-parasite relationships. After colonization of transgenic tobacco by the adventitious plant species Cuscuta reflexa, green-fluorescent protein expressed within tobacco companion cells was detectable within the SEs of the associated parasite (Haupt et al., 2001).

Conversely, this study provides strong evidence that gafp- 1 transcripts and protein may not be moving into the grafted, WT scions of a CG tree species. These results contradict previous research that supports the phloem mobility of GAFP-1 within its host, the achlorophyllic orchid Gastrodia elata. Immunofluorescence studies demonstrated that the GAFP lectin is present within the vascular tissue of terminal corms, and it was proposed that the lectin is transported from the primary (nutritive) to the secondary (terminal) corm of the orchid as well as into the developing flower stem through the SEs (Hu and Huang, 1994). There are no data,
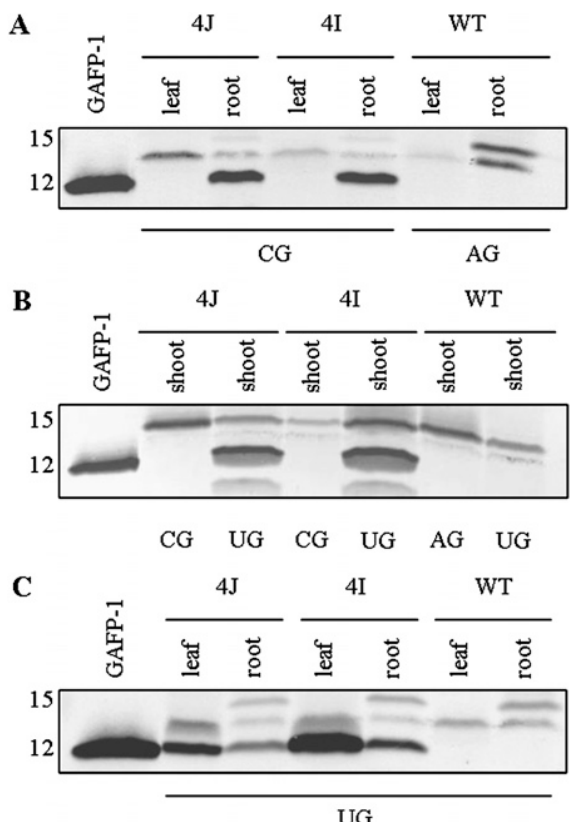

UG

Fig. 3. Immunoblot analysis of protein extracts from chimeric-grafted (CG), autografted (AG), and ungrafted (UG) trees. (A) Leaves and roots from $\mathrm{CG}$ and AG trees; (B) soft shoots from CG, UG, and AG trees; and (C) leaves and roots from UG trees were analyzed for the presence of the GAFP-1 lectin. Recombinant GAFP-1VNF (GAFP-1; expected size $12 \mathrm{kDa}$ ) cleaved from a maltose-binding protein fusion was included as a standard (140 ng total protein). Protein extracts from leaf and root tissues of AG and UG wild-type (WT) trees served as negative controls. The numbers to the left of the figures indicate the size of the protein bands in kilodaltons.

however, to indicate that gafp-1 transcripts are phloem-mobile in G. elata.

As emerging leaves develop on the scion, they make the transition from "sink" to "source," and at this point, they begin to contribute phloem assimilates to the scion translocation stream (Haywood et al., 2005). By routinely pruning the trees, we strived to keep the grafted scions in a "sink" state. There was not a single instance in which our detection procedures gave any indication of gafp-1 mRNA or protein in the grafted, WT leaf tissues of $C G$ trees, even when tissues were sampled shortly ( 2 weeks) after maintenance pruning. Similarly, soft shoots, which were sampled from scions of CG trees between 2 and 6 weeks postpruning, never showed a protein signal at the $12-\mathrm{kDa}$ position. Immunoblots performed on protein extracts from WT leaves of CG $4 \mathrm{~J}$ and CG $4 \mathrm{I}$ trees 8 weeks after budding (4 weeks post bud-flush) did not show GAFP-1 protein signals (data not shown).

We began to sample leaves and soft shoots for the detection of gafp-1 mRNA and protein 2 weeks after maintenance pruning. This should have been an adequate amount of time for the hypothetically phloem-mobile gafp-1 molecular products to move into grafted tissues. Several studies have demonstrated that macromolecules using phloem channels 
will spread relatively quickly within the plant. It has been reported that phloem-mobile genesilencing signals are distributed systemically within a few days in tomato (Voinnet et al., 1998), and in herbaceous heterografts, 3 weeks has been sufficient for the detection of various, imported phloem-mobile transcripts and proteins (Gomez et al., 2005; Haywood et al., 2005; Ruiz-Medrano et al., 1999). Certain phloem-mobile plant viruses, which are thought to travel through the translocation stream as ribonucleoprotein complexes (Santa Cruz, 1999), are capable of spreading systemically in a matter of hours (Gal-On et al., 1994; Ismail et al., 1987) or days (Bennett, 1940; Capoor, 1949; Helms and Wardlaw, 1976; Más and Pállas, 1996) in herbaceous species. If virus movement is being assessed by symptom emergence, fruit tree seedling double-budding experiments have shown that virus particles can move from infected to noninfected tissues in 4 weeks (Fridlund, 1980). Most grafting studies conducted with woody plant material do not determine on a molecular level the amount of time it takes for phloem-mobile virus particles to move into budded tissues (S. Scott, personal communication); however, it has been shown in herbaceous systems that manifestation of disease symptoms in grafted tissues is preceded by the delivery of virus RNA (Más and Pállas, 1996).

It is possible that the GAFP-1 lectin may not be compatible with the phloem transportation machinery of $P$. domestica. Being in a different genetic background, the GAFP1 lectin may move into the translocation stream only to be quickly degraded, or the protein may not be entering the translocation stream at all. In higher plants, the noncellautonomous activity of signaling proteins and transcripts has a significant impact on the coordination of complex developmental and physiological events (Nakajima et al., 2001; Palauqui et al., 1997; Ruiz-Medrano et al., 1999; Xoconostle-Cázares et al., 1999; Yoo et al., 2004) and is likely subject to a certain degree of regulation. Indeed, targeted transport of macromolecules as well as nonspecific diffusion has been observed within symplasmically connected cells and SEs (Crawford and Zambryski, 2000; Itaya et al., 2002; Lucas et al., 1995; Stadler et al., 2005). The concept of a surveillance system controlling the movement of transcripts into specific tissues has been supported by studies on the selective entry of virus-derived posttranscriptional genesilencing signals into the plant shoot apex (Foster et al., 2002). Likewise, Haywood et al. (2005) showed that expressed cucurbit Cmgaip transcripts were able to move into the WT leaf and flower tissues of CG tomato, but not into the fruits produced on the WT scions. Analogous mechanisms likely exist for regulating the delivery of phloemassociated proteins to plant tissues. This statement is congruent with the observation that phloem proteins from Cucurbita maxima have the ability to interact with and increase the size exclusion limit of the plasmodesmata in cotyledon mesophyll cells (Balachandran et al., 1997). Also, the melon RNA-binding phloem protein CmmPP2 was not detected in scion phloem exudates of grafted pumpkin tissues despite the successful translocation of other phloem-mobile melon proteins such as CmmLec17 (Gomez et al., 2005).

Our results suggest that gafp-1 transcripts and protein are not phloem-mobile in CG plum. It remains to be determined whether gafp-1 products expressed in transgenic rootstocks can accumulate in nontransgenic branches and leaves after several years of establishment in the field or in flowers or fruits after significant physiological changes such as the onset/breaking of dormancy and fruiting. Most fruit tree crops are propagated by grafting cultivar tissue onto rootstocks with desirable attributes such as enhanced tolerance to root diseases. Thus, a CG strategy such as we have described could have broader applications for a range of plant systems engineered for root-associated disease resistance. The ability of different GM rootstocks to retain foreign gene products would depend highly on the nature of the expressed protein or transcript and its compatibility with the translocation machinery of the host plant species to which transgenic resistance was being applied.

\section{Literature Cited}

Balachandran, S., Y. Xiang, C. Schober, G.A. Thompson, and W.J. Lucas. 1997. Phloem sap proteins from Cucurbita maxima and Ricinus communis have the capacity to traffic cell to cell through plasmodesmata. Proc. Natl. Acad. Sci. USA 94:14150-14155.

Banerjee, A.K., M. Chatterjee, Y. Yu, S. Suh, W.A. Miller, and D.J. Hannapel. 2006. Dynamics of a mobile RNA of potato involved in a longdistance signaling pathway. Plant Cell 18: 3443-3457.

Bennett, C.W. 1940. Relation of food translocation to movement of virus of tobacco mosaic. J. Agr. Res. 60:361-390.

Boccaletti, S. and D. Moro. 2000. Consumer willingness-to-pay for GM food products in Italy. AgBioForum. 3:259-267. 1 July 2009. $<$ http://www.agbioforum.org $>$.

Bukenya, J.O. and N.R. Wright. 2007. Determinants of consumer attitudes and purchase intentions with regard to genetically modified tomatoes. Agribusiness 23:117-130.

Burton, M., D. Rigby, T. Young, and S. James. 2001. Consumer attitudes to genetically modified organisms in food in the UK. Eur. Rev. Agr. Econ. 28:479-498.

Capoor, S.P. 1949. The movement of tobacco mosaic viruses and potato virus $\mathrm{X}$ through tomato plants. Ann. Appl. Biol. 36:307-319.

Chomczynski, P. 1993. A reagent for the singlestep simultaneous isolation of RNA, DNA, and proteins from cell and tissue samples. Biotechniques 15:532-537.

Crawford, K.M. and P.C. Zambryski. 2000. Subcellular localization determines the availability of non-targeted proteins to plasmodesmatal transport. Curr. Biol. 10:1032-1040.

Foster, T.M., T.J. Lough, S.J. Emerson, R.H. Lee, J.L. Bowman, R.L.S. Forster, and W.J. Lucas. 2002. A surveillance system regulates selective entry of RNA in the shoot apex. Plant Cell 14:1497-1508.
Fridlund, P.R. 1980. Glasshouse indexing for fruit tree viruses. Acta Phytopathologica Academiae Scientiarum Hungaricae. 15:1-4.

Gal-On, A., I. Kaplan, M.J. Roossinck, and P. Palukaitis. 1994. The kinetics of infection of zucchini squash by cucumber mosaic virus indicate a function for RNA 1 in virus movement. Virology 205:280-289.

Gomez, G., H. Torres, and V. Pallas. 2005. Identification of translocatable RNA-binding phloem proteins from melon, potential components of the long-distance RNA transport system. Plant J. 41:107-116.

Haupt, S., K.J. Oparka, N. Sauer, and S. Neumann. 2001. Macromolecular trafficking between $\mathrm{Ni}$ cotiana tabacum and the holoparasite Cuscuta reflexa. J. Expt. Bot. 52:173-177.

Haywood, V., T.-S. Yu, N.-C. Huang, and W.J. Lucas. 2005. Phloem long-distance trafficking of GIBBERELLIC-ACID_INSENSITIVE RNA regulates leaf development. Plant J. 42:49-68.

Helms, K. and I.F. Wardlaw. 1976. Movement of viruses in plants: Long distance movement of tobacco mosaic virus in Nicotiana glutinosa, p. 283-293. In: Wardlaw, I.F. and J.B. Passioura (eds.). Transport and transfer processes in plants. Academic Press, New York, NY.

Hu, Z. and Q.Z. Huang. 1994. Induction and accumulation of the antifungal protein in Gastrodia elata. Acta Botannica Yunnanica 16:169-177.

Ismail, I.D., I.D. Hamilton, E. Robertson, and J.J. Milner. 1987. Movement and intracellular location of sonchus yellow net virus within infected Nicotiana edwardsonii. J. Gen. Virol. 68:2429-2438.

Itaya, A., F. Ma, Y. Qi, Y. Matsuda, Y. Zhu, G. Liang, and B. Ding. 2002. Plasmodesmamediated selective protein traffic between 'symplasmically-isolated' cells probed by a viral movement protein. Plant Cell 14:20712083.

Kim, M., W. Cannio, S. Kessler, and N. Sinha. 2001. Developmental changes due to longdistance movement of a homeobox fusion transcript in tomato. Science 293:287-289.

Lucas, W.J., S. Bouche-Pillon, D.P. Jackson, L. Nguyen, L. Baker, B. Ding, and S. Hake. 1995. Selective trafficking of KNOTTED1 homeodomain protein and its mRNA through plasmodesmata. Science 270:1980-1983.

Más, P. and V. Pállas. 1996. Long-distance movement of cherry leaf roll virus in infected tobacco plants. J. Gen. Virol. 77:531-540.

Nagel, A.K., R. Scorza, C. Petri, and G. Schnabel 2008. Generation and characterization of transgenic plum lines expressing the Gastrodiaanti fungal protein. HortScience 43:15141521.

Nakajima, K., G. Sena, T. Nawy, and P.N. Benfey. 2001. Intercellular movement of the putative transcription factor SHR in root patterning. Nature 413:307-311.

Palauqui, J.C., T. Elmayan, J.M. Pollien, and H. Vaucheret. 1997. Systemic acquired silencing: Transgene-specific post-transcriptional silencing is transmitted by grafting from silenced stocks to non-silences scions. EMBO J. 16: 4738-4745.

Petri, C. and L. Burgos. 2005. Transformation of fruit trees: Useful breeding tool or continued future prospect? Transgenic Res. 14:15-26.

Ruiz-Medrano, R., B. Xoconostle-Cázeres, and W.J. Lucas. 1999. Phloem long-distance transport of CmNACP mRNA: Implications for supracellular regulation in plants. Development 126:4405-4419. 
Santa Cruz, S. 1999. Perspective: Phloem-transport of viruses and macromolecules - what goes in must come out. Trends Microbiol. 7:237241.

Stadler, R., K.M. Wright, C. Lauterbach, G. Amon, M. Gahrtz, A. Feuerstein, K.J. Oparka, and N. Sauer. 2005. Expression of GFP-fusions in Arabidopsis companion cells reveals nonspecific protein trafficking into sieve elements and identifies a novel post-phloem domain in roots. Plant J. 41:319-331.

Voinnet, O., P. Vain, S. Angell, and D.C. Baulcombe. 1998. Systemic spread of sequence-specific transgene RNA degradation in plants is initiated by localized introduction of ectopic promoterless DNA. Cell 95:177-187.

Xoconostle-Cázares, Y. Xiang, R. Ruiz-Medrano, H.L. Wang, J. Monzer, B.C. Yoo, K.C. McFarland,
V.R. Franceschi, and W.J. Lucas. 1999. Plant paralog to viral movement protein that potentiates transport of mRNA into the phloem. Science 283:94.

Yoo, B.C., F. Kragler, E. Varkonyi-Gasic, V. Haywood, S. Archer-Evans, Y.M. Lee, T.J. Lough, and W.J. Lucas. 2004. A systemic small RNA signaling system in plants. Plant Cell 16: 1979-2000. 